\title{
Auditing Research : Evolution, traditions and prospects
}

Citation for published version (APA):

Mock, T. J. (1992). Auditing Research : Evolution, traditions and prospects. Maastricht University. https://doi.org/10.26481/spe.19921027tm

Document status and date:

Published: 27/10/1992

DOI:

10.26481/spe.19921027tm

Document Version:

Publisher's PDF, also known as Version of record

\section{Please check the document version of this publication:}

- A submitted manuscript is the version of the article upon submission and before peer-review. There can be important differences between the submitted version and the official published version of record.

People interested in the research are advised to contact the author for the final version of the publication, or visit the DOI to the publisher's website.

- The final author version and the galley proof are versions of the publication after peer review.

- The final published version features the final layout of the paper including the volume, issue and page numbers.

Link to publication

\footnotetext{
General rights rights.

- You may freely distribute the URL identifying the publication in the public portal. please follow below link for the End User Agreement:

www.umlib.nl/taverne-license

Take down policy

If you believe that this document breaches copyright please contact us at:

repository@maastrichtuniversity.nl

providing details and we will investigate your claim.
}

Copyright and moral rights for the publications made accessible in the public portal are retained by the authors and/or other copyright owners and it is a condition of accessing publications that users recognise and abide by the legal requirements associated with these

- Users may download and print one copy of any publication from the public portal for the purpose of private study or research.

- You may not further distribute the material or use it for any profit-making activity or commercial gain

If the publication is distributed under the terms of Article $25 \mathrm{fa}$ of the Dutch Copyright Act, indicated by the "Taverne" license above, 
Th.J. Mock PhD

\section{AUDITING RESEARCH: EVOLUTION, TRADITIONS AND PROSPECTS}


9206252 
AUDITING RESEARCH:

EVOLUTION, TRADITIONS AND PROSPECTS 


\title{
AUDITING RESEARCH: EVOLUTION, TRADITIONS AND PROSPECTS
}

\begin{abstract}
REDE
in verkorte vorm uitgesproken bij de aanvaarding van het ambt van hoogleraar in de Bedrijfseconomie aan de Rijksuniversiteit Limburg
\end{abstract}

op dinsdag 27 oktober 1992

door

\section{Dr. Th.J. Mock}

Lecture given by Dr. Th.J. Mock on the occasion of his appointment as Professor of Business Administration

at the University of Limburg

Maastricht

Tuesday, October 27, 1992 


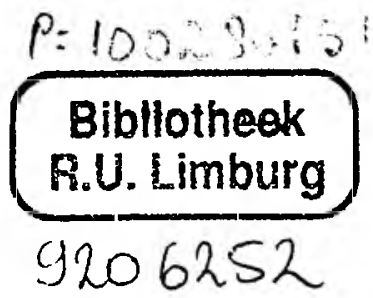


Dedicated to my Father

Raymond D. Mock

who, although not an auditor by training or profession, exemplifies the best of the ethical and professional norms of the auditing profession.

1992 Palos Verdes, California, USA

Copyright T. J. Mock

All rights reserved. 


\section{CONTENTS (INHOUD)}

1. Introduction

p. 1

- Definition of auditing

p. 2

- Overview of the external audit process

p. 3

2. Evolution of audit research

p. 4

- Classical, modern and international periods

p. 4

- Stimuli to audit research

p. 6

- Types of audit research

p. 9

3. Illustrations of audit research

p. 10

- Internal Control Evaluation (ICE)

p. 11

- Risk Assessment and Audit Planning

p. 14

4. Overall Observations, Implications

p. 15 and Research Prospects

Notes (Noten)

p. 17

References (Literatuur)

p. 18

Acknowledgments (Verantwoording)

p. 20 


\title{
AUDITING RESEARCH - EVOLUTION, TRADITIONS AND PROSPECTS
}

\author{
by \\ Theodore Jaye Mock', PhD
}

\section{Introduction}

As recently as only 14 years ago, the amount of audit research that had been published in North America was almost nil and one could give a very short lecture on its evolution and traditions. This observation would certainly hold for the world as a whole.

But in the last decade or so, this has changed dramatically! The most obvious evidence of this change is the Maastricht Accounting \& Auditing Research Center (MARC) whose inauguration we are celebrating this afternoon. It is particularly noteworthy that MARC has incorporated the term auditing within its title. The City of Maastricht, the Province of Limburg and the Rijksuniversteit Limburg are to be congratulated for their support of this important research center which has already become instrumental in the European audit research tradition.

My inaugural lecture has two primary objectives. The first is to sketch the evolution and limited traditions of audit research and to identify some of the factors that seem to have stimulated this research. Second, I will provide some detail on two types of audit research that I personally have been involved with. Both lines of research relate to audit planning, first with how the evaluation of accounting controls effects judgments concerning the amount of audit evidence to collect. The second deals with how the assessment of various audit risk factors impacts overall audit planning.

These examples of audit research have been selected as I feel they demonstrate some benefits of audit research which is lacking in much of academic research in accounting, in economics and in universities in general. In particular, these examples provide positive evidence of the expected value of supporting activities such as MARC and the Maastricht Audit Research Symposium (MARS)

The academics in the audience will note that these two lines of studies have utilized a diverse set of research strategies including laboratory experimentation, decision process tracing ${ }^{2}$, multi-attribute decision modeling, and survey methods. My lecture will end with some audit research contributions I have identified in reviewing the general audit research literature and with some speculations on implications and future prospects for auditing research. 


\section{Definition of Auditing}

Given that many of those in the audience today and many who may read the published version of this lecture have little or no exposure to auditing, some discussion of auditing as an activity and as a profession is clearly called for. A general definition, adapted from a recent textbook by Arens and Loebbecke (1991) is:

Auditing is a process by which a competent, usually independent person accumulates and evaluates evidence about an entity or unit for specified purposes.

The purposes of an audit can be quite general. For example my two sons, Christopher and Cameron, are missing a week of school in order to attend this lecture. And they, I hope, have promised their teachers that they would diligently do their homework during their trip. Whether they have satisfied this promise or not is something that could be audited. In this case the purpose might be to satisfy their teachers (and parents) that they had done their homework, my sons would be the entity to be audited, the evidence accumulated might be completed assignments or observations by their mother, Mary Jo, that they were indeed studying on the trip over here. Finding an independent person to plan and accomplish such an audit would not be difficult in this particular audience.

Auditing is of course significantly more complex if one is attempting to audit compliance with environmental quality standards, performing operational audits of departments within multinational corporations, auditing compliance with political financing laws or performing financial statement audits.

There are two images of auditing or of an auditor I like to leave with any general audience I address. Being from Southern California, this is partly an attempt on my part to counteract the somewhat negative image of accountants/auditors which is portrayed by Hollywood. The first image is that of Sherlock Holmes. Here one can imagine someone who is focusing on the excitement of planning and collecting evidence of criminal activities, of inventing who done it hypotheses, and eventually of catching the culprits!

The second image, that should be right at home in an academic environment, is that of the scientific researcher image of auditor. Here the auditor is viewed as using scientific methods to collect evidence and as relying on statistical and other forms of inference in order to assess the likelihood that certain hypotheses or theories are true. In financial statement auditing an example of a relevant null hypothesis might be: There is no significant difference between amounts reported by a corporation in their financial statements and the true financial state of the corporation. 
Overview of the External Audit Process

Given that the examples of audit research I will discuss relate primarily to financial statement audits which are commonly referred to as external audits, it will probably be useful to provide an overview of these types of audits. The main steps in a financial statement audit are listed in Table I, An Overview of the External Audit Process. This type of audit is often referred to as an external audit as it is conducted by auditors external to the

Table 1

OVERVIEW OF THE EXTERNAL AUDIT PROCESS

ORGANIZING

- CLIENT ACCEPTANCE DECISION

- ENGAGEMENT TERMS

PLANNING

- SELECT ENGAGEMENT TEAM

- ASSESS AUDIT RISK

- OBTAIN APPROPRIATE CONSULTATION

- PRELIMINARY ANALYTICAL REVIEW

- SELECT MATERIALITY \& PRECISION

- DEVELOP PRELIMINARY AUDIT PLAN (NATURE, EXTENT/SCOPE, TIMING)

- INTERNAL CONTROL EVALUATION (ICE)

- DESIGN AUDIT TESTS

(COMPLIANCE, ANALYTICAL REVIEW, DETAIL TESTS)

TESTING \& EVALUATION

- PERFORM AUDIT TESTS

- EVALUATE TEST RESULTS

(REVISE IF NECESSARY)

- REVIEW SUBSEQUENT EVENTS

REPORTING

- REVIEW OVERALL FINANCIAL STATEMENT REASONABLENESS

- REVIEW DOCUMENTATION \& FORM OPINION

- DRAFT AND ISSUE AUDIT REPORT 
organization being audited. In the Netherlands and the United States these audits are usually performed by licensed auditors. ${ }^{3}$

Table 1 displays in a simplified, sequential set of steps, the four major phases of any audit: 1) organizing, 2) planning, 3) testing \& evaluation, and 4) reporting. The parts of the audit that are the focus of the audit research discussed later are highlighted in bold face in the table and are both within the planning phase.

The first series of studies involves internal control evaluation and its effect on the design of audit tests, specifically what are called tests of details. Internal accounting control evaluation refers to an assessment of controls such as requiring management approvals prior to expending travel funds or the incorporation of check digits in computer processing systems. If such controls are found to be working effectively within an accounting system, the auditor can place some reliance on such controls to judge whether material errors exist.

The second series of studies involves the assessment of audit risk within the planning phase of an audit ${ }^{4}$. Audit risk is generally thought to include 1) the risk of poorly functioning controls such as those referred to above, 2) the inherent risk in the client's accounting system of creating errors and 3 ) the risk of the audit program not detecting such errors. Audit programs are thought to differ significantly depending on whether the client is judged to exhibit low, moderate or high risk of financial statement error or irregularity. Both internal control evaluation and risk assessment are critical to the effectiveness and efficiency of an audit.

\section{Evolution of Audit Research}

Although basic audit practice developed over a number of centuries, modern auditing was a product of the industrial revolution, of the separation of management and ownership. and of the growth of the limited liability company. For our purposes, modern auditing can be thought to have begun at the beginning of this century. Table 2 includes a graph that depicts the quantity of audit research beginning with the year 1900 .

\section{Classical. Modern and International Periods}

As is indicated in Table 2, one can partition audit research into three periods: 1) a classical period that was dominated by practice-derived research beginning in about 1900 and extending until 1970), 2) a modern research period that began about in 1970 and continues even today and 3 ) an overlapping period of internationalization that began around 


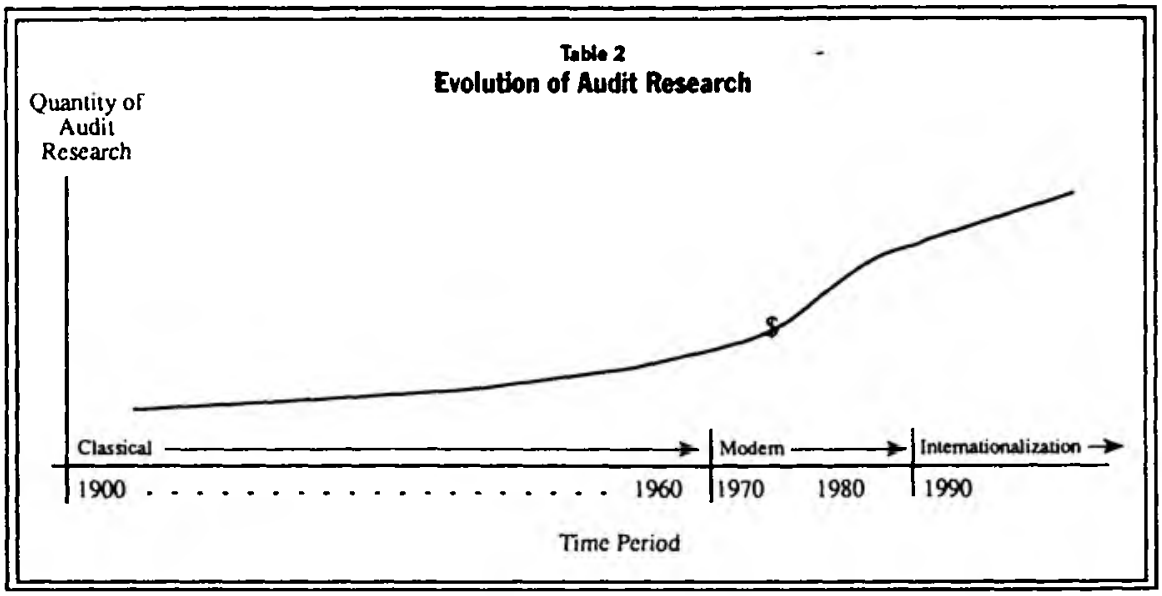

1990. Two trends are of note during these periods. First is the rather long period of low research activity. The second trend is the prominence of practice-derived research within this so-called classical period. By practice-derived I mean that the research activities that resulted in knowledge concerning auditing were conducted primarily within the audit firms, that is by practitioners. Practice clearly did lead academic research during this period. But because this research was conducted by those with limited scientific training and there was little concern with scientific method, many of the findings lacked scientific basis. For example, certain audit sampling methods were based on ad hoc, judgmental rationale rather than rigorous statistical theory.

During this period there was the almost total lack of academic interest in auditing and thus a lack of any research literature or tradition. Two noteworthy exceptions in the literature are Limperg's "De functie van de accountant en de Leer van het gewekte vertrouwen" ("The Role of the Accountant and the Theory of Inspired Confidence") (1932 and 1933) and the American Accounting Association's research monograph The Philosophy of Auditing by Mautz and Sharaf (1961). Both of these publications were efforts by academics who had significant practice experience to explore the basic economic and professional concepts that underlie auditing.

I have labeled the period of approximately 1970 to 1990 as the modern period of audit research and this would be the time when formal, scientifically-based research began to take off as indicated by the dramatic upturn in the quantity of research line in Table 2 .

The period following this is labeled internationalization as is evidenced by a number 
of world-wide activities - the most obvious being the organization of the Maastricht Accounting \& Auditing Research Center and the Maastricht Audit Research Symposium. In the following section I identify some of the forces or stimuli that seem to have led to this extraordinary increase in audit research activity, primarily within North America.

\section{Stimuli to Audit Research}

In the United States the years surrounding 1970 were marked by a number of events, traditions and pressures that acted to stimulate audit research. For example, rapidly changing audit environments, technology, and economic complexity rendered judgmental sampling methods less acceptable and led to audit sampling research. So-called audit failures led to regulatory and political pressure and the need for and recognized value of academically-supported audit standards.

Table 3 presents a classification and chronology of some of the key stimuli that continued to propel audit research during the late 1970s and throughout the 1980s.

\section{Funded Research and Professorships}

Within what I have called the modern period of audit research, the event that probably had the greatest effect on stimulating research was the origination and funding of the Peat Marwick Mitchell (PMM) Research Opportunities in Auditing (ROA) program. The ROA program both published an extensive compilation of possible audit research issues in a monograph titled Research Opportunities in Auditing (PMM, 1976) and provided significant funding for the research. This program was quite unique in that the funds (approximately US $\$ 1,000,000$ ) were designated purely for academic projects. These funds were granted with no (few) practice derived constraints to the research and a broad-based concept of auditing was used (not just external, financial statement auditing).

The amount of funding for audit research has steadily increased as is indicated in Table 3 with, for example the initiation of a funding program by the Institute of Internal Auditors, with the funding of specialized audit professorships by the international auditing firm of Price Waterhouse, and by the funding of $\mathrm{PhD}$ scholarships by several of the large auditing firms.

\section{PhD Programs}

Within universities in the United States, there has been a tradition of formal PhD programs in business and accounting beginning in the 1950s. These programs typically are designed for full-time students, are highly structured, include ample amounts of researchoriented coursework, and can be completed in about four years. This tradition is significantly different from doctoral programs in the Netherlands. By the 1970s, such programs in the United States were creating a significant supply of research-qualified PhDs. On the demand side, US business schools and accounting departments expanded rapidly 


\section{Table 3}

Classification and Chronology ${ }^{6}$ of Some Key Stimuli to Audit Research

- Academic Symposia

1973 New York University Audit Research Symposium organized by PMM

1974 University of Kansas Auditing Symposium Initiated

1976: Illinois Symposium on Auditing Research Initiated

1983: University of Southern California Audit Judgment Symposium Initiated

1989: University of Waterloo (Canada) Audit Conference Initiated

- Academic Auditing Association Formed

1976: American Accounting Association Auditing Section Formed

- Funded Research \& Professorships

1976 PMM Research Opportunities in Auditing Competitive Grant Program Initiated (Original Fund of $\$ 1,000,000$ Was Established)

1977: Price Waterhouse Audit Professorships Established at Several Universities

1982: Institute of Internal Auditors Research Program Initiated

\section{- PhD Programs}

1981: Specialized PhD Course in Auditing Offered at University of Southern California

- Academic Journals and Other Publications

1975 Journal of Accounting Research Special Audit Research Issue

1976 Publication of Research Opportunities in Auditing by Peat, Marwick, Mitchell (PMM; now called KPMG Peat Marwick)

1980: Auditing: A Journal of Practice \& Theory Began by AAA Auditing Section 1989: Accounting. Organizations and Societv Issue on Audit Judgment Research 
during this period and ever increasing pressure to "publish or perish" was exerted by the more traditional, research-oriented segments within universities. Such events led to both a greater demand for audit knowledge and research and a greater potential supply of audit research from the largely $\mathrm{PhD}$ trained accounting faculties. These events culminated in the mid 1970s and thus the dramatic upturn in audit research.

\section{Academic Symposia}

A third major category of stimuli to research noted in Table 3 is the emergence of a number of continuing academic conferences and symposia that focused on audit research. These include the initiation of a number of continuing academic conferences at major universities: the University of Kansas, the University of Illinois, the University of Southern California and the University of Waterloo in Canada. Both the Kansas and Illinois conferences published the research papers that were presented and thus were a major demand for and repository of early audit research. No such opportunity existed in Europe for audit researchers during this period. The MARS audit symposium which is sponsored by MARC is now filling this void in the Netherlands.

\section{Academic Auditing Association Formed}

Another very important factor in the emergence of audit research in North America was the role played by a group of American Accounting Association (AAA) members who had a particular interest in auditing. In 1976 within the AAA a special Auditing Section which now numbers almost 2,000 members was formed. This Section has promoted research in many ways including organizing specialized audit research sessions at national and regional meetings and publicizing research opportunities in its newsletter. Similar activities may be expected from the European Accounting Association, but to this date no such specialized academic audit section has been organized.

\section{Academic Journals}

In 1980 the Auditing Section started a specialized journal Auditing: A Journal of Practice \& Theory devoted entirely to publishing scholarly and applied audit research. This journal has experienced a high degree of academic credibility and success and is an interesting example of the integration of applied and theoretical research. Other academic journals have shown an interest in auditing research including the Journal of Accounting Research which has published several issues focusing on audit research and Accounting. Organizations and Societv which is published in the United Kingdom.

Although there were a number of other important events which affected audit research during this period, the above is a sample of the most important ones which took place in North America. Toward the end of this period the international community took an increasing interest in audit research. I have compiled a number of these events in Table 
4. These items cover the full range of academic activities including visiting faculty programs, research conferences, and in the case of the University of Limburg, the initiation of a research center with audit research as one of its major thrusts.

\begin{tabular}{|c||}
\hline Table 4 \\
INTERNATIONAL STIMULI TO AUDIT RESEARCH \\
1980'S UNIVERSITY INTEREST \\
- UNIVERSITY OF OTAGO, NEW ZEALAND: \\
VISITING AUDIT FACULTY \\
FULBRIGHT SCHOLAR IN AUDITING \\
- NORWEGIAN SCHOOL OF ECONOMICS \& BUSINESS: \\
ADVANCED AUDITING ACADEMIC PROGRAM \\
VISITING AUDIT FACULTY \\
SCANDINAVIAN AUDIT SYMPOSIUM \\
- UNIVERSITIES OF TILBURG AND LIMBURG, THE NETHERLANDS: \\
AUDIT LECTURES \\
BOND UNIVERSITY, AUSTRALIA \\
- UNIVERSITY OF WATERLOO, CANADA \\
1980'S \& 1990'S \\
- HEIGHTENED INTEREST IN INTERNATIONAL STANDARDS \\
- EUROPEAN ECONOMIC COMMUNITY \\
- UNIVERSITY OF LIMBURG: \\
MAASTRICHT ACCOUNTING \& AUDITING RESEARCH CENTER \\
PART-TIME PROFESSORSHIP IN AUDITING \\
MARS AUDIT SYMPOSIA
\end{tabular}

Tvpes of Audit Research

A final item I have compiled which provides some perspective on the history of audit research is a list of types of research conducted which are listed in Table 5. This list was compiled primarily by reviewing the published literature and forming an informal taxonomy of research. It clearly provides a view of a robust research area that has studied a broad 
number of topics and used a broad variety of scientific methods.

\begin{tabular}{|c|c|}
\hline \multicolumn{2}{|c|}{$\begin{array}{c}\text { TABLE 5: } \\
\text { VARIETIES OF AUDIT RESEARCH }\end{array}$} \\
\hline Statistical Sampling & - Decision Support, Expert Systems \\
\hline Analytical Review & Risk Assessment, Audit Risk \\
\hline EDP \& Technology & Audit Liability \\
\hline Internal Control Evaluation & $\begin{array}{l}\text { Economic and Social Role of } \\
\text { auditing }\end{array}$ \\
\hline Fraud, White Collar Crime & Audit Theory \\
\hline $\begin{array}{l}\text { Audit Team Management } \\
\text { Audit Quality, Quality Control \& } \\
\text { Audit Review }\end{array}$ & $\begin{array}{l}\text { Auditor Ethics } \\
\text { Audit History }\end{array}$ \\
\hline $\begin{array}{l}\text { Attributes of Audit Procedures \& } \\
\text { Evidence }\end{array}$ & Computational Modeling \\
\hline Decision Theory Applications & Cognitive Science Paradigm \\
\hline $\begin{array}{l}\text { Auditor Juogment \& Decision } \\
\text { Making }\end{array}$ & Audit Markets \\
\hline Pricing of Audit Services & Policy Capturing Research \\
\hline
\end{tabular}

3. Illustrations of Audit Research: Studies into Internal Control Evaluation and Risk Assessment in Audit Planning

In this portion of my lecture sketches are provided of the two series of audit research introduced earlier. Both deal with audit planning. These have been selected to provide some indication of the wide variety of audit research that exists, to show the close link between theory and practice in audit research and to introduce a promising area of research. 


\section{Internal Control Evaluation (ICE)}

The first line of research is of interest from an historical perspective given that it is a direct result of PMM's ROA activities and it is an early example of some of the features that tend to distinguish audit research in general - particularly the use of multi-method studies and the use of audit tasks which exhibit high external validity. These studies may be called the ICE studies as they focus on Internal Control Evaluation of the controls designed into clients' accounting systems. As noted earlier, the auditor may assess, test and rely on controls such as formal management authorization of expenditures or computer check digits in planning audit tests. ${ }^{7}$ Such internal control evaluation normally begins within the planning phase of the audit.

From an historical perspective, two features of the US audit environment in the 1970s are important when considering this line of research. First, partly as a result of a number of accounting-related financial frauds and so-called audit failures the subject of internal accounting controls was receiving unprecedented attention from the U.S. Congress, from regulators and from the business press. Second, auditing firms were facing both rapid technological change and increasing competitive pressures and thus were keenly interested in research that might make the audit more effective and efficient.

Table 6 presents an overview of this line of research organized by a number of publications that have resulted. In this lecture, I will focus on the research design and the overall study results as reported in Mock and Turner, 1981.

\begin{tabular}{||c|l|}
\hline \multicolumn{2}{|c|}{ Table 6} \\
Overview of the Internal Accounting Control (ICE) Studies \\
\hline Reference and Date & \multicolumn{1}{|c|}{ Summarv of Research Method } \\
\hline Mock and Turner, 1979 & $\begin{array}{l}\text { Initial experiments, 2x2 design, 80 } \\
\text { experienced auditor subjects }\end{array}$ \\
\hline Mock and Turner, 1981 & $\begin{array}{l}\text { Complete set of experiments, 2x5 design, } \\
\text { 200 experienced auditor subjects }\end{array}$ \\
\hline Mock and Watkins, 1982 & $\begin{array}{l}\text { Multivariate modeling of auditor } \\
\text { judgments }\end{array}$ \\
\hline Biggs and Mock, 1983 & $\begin{array}{l}\text { Process tracing (protocol) experiment, } \\
\text { 4 experienced subjects }\end{array}$ \\
\hline Mock and Willingham, 1983 & $\begin{array}{l}\text { Discussion of implementation of research } \\
\text { within PMM's audit approach } \\
\text { (SEADOC) }\end{array}$ \\
\hline
\end{tabular}


The Basic Research Issues and Methods

Given the state of the extant literature in the 1970s, a basic research plan was designed to address the following questions:

To what extent and in what manner do experienced auditors respond to different evidence of the effectiveness of internal controls?

What factors do auditors consider in making and in justifying their audit planning judgments?

Are auditors' decisions influenced by different types of guidance, decision aids, and approaches?

Are auditors' judgments influenced by heuristics, training, experience, or other behavioral differences?

A multi-method research approach was employed to address these research questions and is summarized in Table 7. The studies consisted of a series of five related field experiments and a process-tracing (protocol analysis) study, both using the same audit case. The research was experimental in that versions of the audit case differed in terms of whether the system of internal accounting controls was fair or strong and as to the type of guidance provided to subjects. In interpreting the findings which are summarized below, note that the underlying audit case was realistic (it was taken from an actual audit engagement), comprehensive, and was based on what at the time were the most advanced state-of-the-art techniques of documenting, analyzing, and evaluating internal accounting controls.

\begin{tabular}{|l|l|l|l|l|l||}
\hline \multicolumn{7}{|c|}{ Table 7 } \\
\hline $\begin{array}{l}\text { Experiment } \\
\text { Treatments }\end{array}$ & $\begin{array}{l}\text { No } \\
\text { Guidance }\end{array}$ & $\begin{array}{l}\text { Narrative } \\
\text { Guidance }\end{array}$ & $\begin{array}{l}\text { Structured } \\
\text { Guidance }\end{array}$ & $\begin{array}{l}\text { Statistical } \\
\text { Approach }\end{array}$ & $\begin{array}{l}\text { Manager } \\
\text { Review }\end{array}$ \\
\hline $\begin{array}{l}\text { Fair } \\
\text { Controls }\end{array}$ & $\mathrm{N}=18$ & $\mathrm{~N}=19$ & $\mathrm{~N}=18$ & $\mathrm{~N}=17$ & 15 Teams \\
\hline $\begin{array}{l}\text { Strong } \\
\text { Controls }\end{array}$ & $\mathrm{N}=18$ & $\mathrm{~N}=18$ & $\mathrm{~N}=17$ & $\mathrm{~N}=17$ & 15 Teams \\
\hline
\end{tabular}


In solving the experimental case, the 206 experienced auditors who participated were asked to make specific planning recommendations concerning four audit procedures which were part of an audit program related to sales invoice processing and accounts receivable. In addition, they were asked to document the reasoning for their recommendations in openended "rationale memos," or in detailed questionnaires. analyzed:

The effects on the auditor's judgments of the following factors were statistically The quality of the system of internal accounting controls as evidenced by compliance test results;

Amount and nature of auditor guidance;

Audit approach;

Demographic characteristics of subjects (e.g., training, experience); and

Variables documented in auditor's rationale memos (e.g., intended reliance on controls, actual reliance on various controls, quality of audit evidence, audit risk).

\section{Overail Results}

The general results of the basic research phases showed that the study and evaluation of internal controls is much more complex than was previously believed. For example, the results showed:

Significant variability and lack of consensus in recommendations among auditors. (The majority of this variance was not explainable in terms of the manipulated or measured independent research variables.)

Significant variability among auditors' interpretations of the nature and relevance of the audit procedures, internal accounting controls, and other audit factors;

Significant variability in auditors' decision processes in terms of information search, alternatives considered, criteria applied, and heuristics utilized; and

Lack of comprehensiveness in the auditors' documentation of the rationale for their recommendations.

The sheer complexity of the task implied that there were many feasible strategies that could be justified in such an environment, thus complicating the review process, the possibility of providing specific guidance or decision aids or of specifying professional 
standards for this activity. On the other hand, the existence of significant variability in sample size decisions between auditors who were given essentially the same audit task implies a significant possibility of over or under auditing in this type of task and thus opportunities for improved audit efficiency and risk control.

The research did lead to a number of other findings, both of academic and practical interest. For example in the academic area, evidence was obtained concerning the use of certain decision heuristics first identified in psychological studies and detailed evidence of auditor decision processes was obtained in the process-tracing studies (Biggs and Mock, 1983). In the applied domain is the use of some of the research results by Peat Marwick Mitchell in developing a new, more efficient approach to internal accounting control and alternative sampling approaches. This type of implementation research is documented in Mock and Willingham (1983).

\section{Risk Assessment and Audit Plannning}

The second line of research to be briefly introduced in this lecture also relates to the planning phase of an audit. Risk assessment is important within all phases of an audit and has been the focus of many audit research efforts. For example, during audit planning the audit team is expected to control overall audit risk by assessing three primary risk components: the inherent risk of material errors and irregularities, control risk which in essence is the focus of internal accounting control assessment and the detection risk of the various audit procedures selected and utilized. These risk concepts, risk assessment and aggregation have been discussed extensively within the literature ${ }^{8}$.

The particular series of studies summarized here began with a two-year study of 159 actual audit engagements and used econometric modeling methods to assess relationships between various audit risk measures and audit program planning decisions (see Mock and Wright, 1991). Among the findings in this study were that perceived risk changed little within the two-year period in this sample. It was also observed that changes in the amount (extent) of audit testing, as opposed to the timing of audit procedures or the type (nature) of procedures selected, was the primary method used by auditors to adapt to changes in risks.

The original study (Mock and Wright, 1991) is now being replicated and extended in multiple year studies in the United States, in the Netherlands and in Australia. The Dutch extension is a cooperative venture by MARC and The Limperg Institute and the planning committee includes participation from the four largest Dutch auditing firms. The research is designed to address three main research questions which are relevant to both audit practice and to the audit research community: First, to what extent do audit risk factors vary between clients within a particular industry group and over time for a two to four year time period? Second, for a specific audit area such as accounts which relate to sales and accounts receivable and specific audit assertions, to what extent do audit programs differ between clients and over time? Third, if significant differences in risks are observed, 
either between clients or over time, are there systematic ways in which auditors adjust audit programs for these differences and changes?

\section{Significance of the proiect to the Dutch audit community}

Completion of this project will be valuable for audit practice, for the academic body of knowledge and for the general prestige of the academic auditing community. To this date there have been few empirical studies of audit risk in the Dutch environment?. Thus, the Dutch audit profession has little valid research evidence concerning which risk factors actually differ between clients and over time. Further, it is unclear how experienced auditors react to differences by altering the nature, extent or timing of audit procedures. Such knowledge should permit audit firms to focus attention on those factors which do indeed differ and to review carefully whether audit effort is being efficiently and effectively allocated. Such knowledge should be useful for both firm and academic training methods.

\section{Overall Observations, Implications and Research Prospects}

In this final section of my lecture, a summary is presented of some overall observations I have gained concerning audit research and some of their implications for education and practice. These observations are based upon an extensive review of the literature and interaction with academics and practitioners during a number of lectures primarily in The Netherlands and the US. ${ }^{10}$

The first observation is that audit research is evolving at a tremendous rate! This should be evident in the graph in Table 1 and by even a cursory review of the literature. When I first began conducting PhD seminars in auditing in about 1980 it was quite easy to review the entire audit research literature. Now one can devote entire semesters to only one specialized area such as audit judgment research or markets-based audit research. The implications of this for education is something the Rijksuniversiteit Limburg is reacting to in a very proactive manner: educators and students must be trained; curriculum must be updated; funding is critical; and there exists significant opportunity for excellence and distinctiveness of academic programs which choose to focus on audit research.

The second observation is that audit research in the US and Canada has had and is having real impact on practice. As research and development improves audit quality and efficiency, some firms may not be able to compete effectively. The potential for improved, broadened audit practice is significant. Practice has been improved through statistical sampling and analytical review techniques and through the development of practice aids, documentation methods, expert systems, and automation.

Audit research also provides the knowledge for improved standards. In fact, , in the United States there is now a tradition of basing standards to some degree on research (e.g. the Auditing Standards Board, and the Commission on Fraudulent Financial Reporting) and 
there have been a number of US auditing standards that have been influenced directly by audit research. The standards setting authorities continue to look to audit research and in the spring of 1992 the American Institute of CPAs held an "expectations gap" symposium to consider research implications for audit standards. Lastly, audit practice has the opportunity to support and alter nature of accounting education in ways that will directly benefit practice; although the benefits will likely be more long-run than short-run.

A third general observation is that audit research has contributed significantly to research in the mother disciplines such as statistics, psychology, artificial intelligence and cognitive science. In statistics early audit research into dollar unit sampling led to some novel statistical distribution theory and work on applied Bayesian statistical inference. In psychology and decision theory, audit researchers have provided both supportive findings and differential results in a task rich environment. The primary areas of such research have been in decision policy capturing (e.g. Lens models and process tracing), in heuristics and biases research and in research on inference and probabilistic reasoning. In the area of artificial intelligence, audit research has been in the forefront in building expert systems and in expert system validation. In cognitive science, research contributions may be found in understanding the nature of expertise and expert reasoning, in the nature of knowledge and knowledge bases and in the building of cognitive models.

In viewing the horizon, the research prospects in auditing also seem excellent. It is not difficult to identify numerous research issues and streams of research which are emerging. Some of these would include the study of the importance of auditor's risk attitude, the use of Bayesian nets and influence diagrams as models and representations of probabilistic reasoning, the study of cultural differences in decision and judgment weightings, and the impact of data processing and decision-support technology.

I am very excited about the kinds of findings, history and contributions I have attempted to sketch in my lecture. The prospects for continued audit research contributions both to practice and to academia are significant and interesting traditions are being extended and created by our activities. I am positive the Rijksuniversiteit Limburg and the Maastricht Accounting \& Auditing Research Center are and will continue to be a significant participant in this process and that tonight's celebration will MARC the formal beginning of an important tradition of research and development. 
Notes (Noten)

1. Th. J. Mock is Arthur Andersen Alumni Professor, University of Southem California and Part Time Professor, Rijksuniversiteit Limburg. Professor Mock received his PhD in business administration from the University of California, Berkeley in 1969 and has earned degrees in mathematics and finance from The Ohio State University.

2. Decision process tracing studies are also often referred to as protocol studies. See Biggs and Mock, 1983 and Klersey and Mock, 1989, for details.

3. In the USA the term CPA or Certified Public Accountant is used. In the Netherlands the term registered accountants (Registeraccountants) is used. In either case the term is somewhat of a misnomer as the functions these professionals play is much more of an auditing than an accounting function.

4. Audit risk assessment does occur within other phases of an audit, however the simplified model in Table 1 focuses on risk assessment in planning an audit.

5. Peat Marwick Mitchell later merged with a number of international auditing firms including the Dutch firm of Klynveld Kraayenhoff \& Co. and became KPMG Peat Marwick in the United States.

6. The dates of many of these events are approximate as they are based in some cases on secondary sources.

7. Felix and Niles (1988) have provided an extensive review of this entire line of research. However, my observations will be limited to internal control studies in which I personally participated.

8. See, for exampie, Mock and Vertinsky, 1985.

9. E.g. Schilder, et al., 1991 and Claessens, 1992.

10. It is of some interest, perhaps, that the first lecture I prepared on this general topic was presented at the Catholic University in Tilburg, the Netherlands, in 1987. A number of members from the Limperg Institute attended this particular lecture and their participation stimulated my interest in this area. 


\section{References (Literatuur)}

Ab'del-kahlik, A. R. and I. Solomon, (eds.), Research Opportunities in Auditing: The Second Decade... : American Accounting Association Auditing Section, 1988.

Auditing Standards Board, 1983, Audit Risk and Materiality in Conducting an Audit, SAS No. 47, AICPA.

Auditing Standards Board, 1988, Consideration of the Internal Control Structure in a Financial Statement Audit, SAS No. 55, AICPA.

Arens, A. and J. Loebbecke, Auditing: An Integrated Approach, Englewood Cliffs, N.J., Prentice Hall, (5th. ediritón), 1991.

Ashton, R. H., 'An Experimental Study of Internal Control Judgments', Journal of Accountina Research. Spring, 1974.

Bedard, J., 'An Archival Investigation of Audit Program Planning', Auditing: A Journal of Practice and Theory, Fall, 1989.

Bedard, J, G. Gray and T. J. Mock, 'Decision Support Systems and Auditing', Advances in Accounting. 1984.

Bigg's; S. F. and T. J: Mock, "An Investigation of Auditor Decision Processes in the Evaluation of Internal Controís and Aúdit Scope Decisions", Journal of Accountina Research. 1983.

Biggs, S. F. and T. J. Mock, "Criteria Auditors Utilize in the Evaluation of Internal Accounting Control," Pacific Accountina Review. 1989.

Biggs, S. F., T. J. Mock and P. R. Watkins, "Auditor's Use of Analytical Review in Audit Program Design'," The Accounting Review, Jan. 1988.

Biggs,S. F., T. J. Mock and P. R. Watkins, Analytical Review Procedures and Processes in Auditing. Research Monograph, Canadian Certified General Accountants Research Foundation, 1989.

Claessens, M. J. A., The Asseissment of Inherent Risk and Management Quality by Dutch Auditors:,'. European Accounting Association Annual Conference, Madrid, Spain, 1992.

Felix, W. L, and M. Niles, 'Research in Internal Control Evaluation', Auditing: A Journal of Practice'\& Theor. (1988).

Gray, G. L. T. E. McKee, and T. J. Mock, The Future Impact of Expert Systems and Decision Support Systems on Auditing", Advances in Accounting, 1991.

Holstrum, G. L., T. J. Mock and R. N. West, The Impact of Technologv on Auditing - Moving Into The 21st Century. Institute of Internal Auditors, 1988.

Klersey, G. and T. J. Mock, 'Verbal Protocol Research in Auditing,' Accounting. Oraanizations. and Societv. 1989. 
Kreutzfeld, R. W., and W.A. Wallace, 'Error Characteristics in Audit Populations: Their Profile and Relationship to Environmental Factors', Auditing: A Journal of Practice and Theory. Fall, 1986.

Limperg. Th., "De functie van de accountant en de Leer van het gewekte vertrouwen" ("The Function of the. Accountant and Theory of Inspired Confidence', Maanblad voor Accountancv en Bedriefshuishoudkunde. (1932. 1933) and The Social Responsibility o the Auditor. Limperg Institute, Amsterdam, 1965.

Lin W. T., T. J. Mock and A. Wright, The Use of the Analytic Hierarchy Process as an Aid in Planning the Nature and Extent of Audit Procedures', Auditing: A Journal of Practice and Theory. Fall, 1984.

Mautz, R. K. and H. A. Sharaf, The Philosophy of Auditing. American Accounting Association, 1961.

Mock, T. J. and A. Schilder, "Proposal for a Joint Audit Research Study of Audit Risk Factors and Thigir Relationship to Audit Programs', Maastricht Accounting \& Auditing Research Center, Rijksuniversiteit Limburg, October, 1991.

Mock, T. J. and J. L. Turner, Internal Accounting Control Evaluation and Auditor Judament. Audit Research Monograph \#3. American Institute of CPAs, 1981. (Reprinted in Spanish. The Mexican Institute of Public Accountants, 1985).

Mock, T. J. and J. L. Turner, The Effect of Changes in Internal Controls on Audit Programs, Behavioral Experiments in Accountina II. (T. J. Burns. Ed.). The Ohio State University. 1979.

Mock, T. J. and P. R. Watkins, The Modeling of Auditor Judgment Based on Two Methods of Auditor Rationale Documentation. The Fourth Svmposium on Auditino Research. University of llinois (1982).

Mock, T. J. and J. J. Willingham, An Improved Method of Documenting and Evaluating a System of : Internal Accounting Control', Auditing: A Journal of Practice and Theory. (Spring. 1983).

Mock, T. J. and I. Vertinsky, Risk Assessment in Accounting and Auditing, Research Monograph No. 10, . Canadian Certified General Accountants' Research Foundation, (1985)..

Mock, T. J. and A. Wright, The Relationship Between Inherent and Control Risk Factors and Auditor:Evidential Planning Judgments;, Proceeding of the 1991 AAANZ Conference. Brisbane ,Australia, 1991.,

Mock T. J. \& M. Washington, "Risk Concepts \& Risk Assessment in Auditing"; Advances in Accounting. 1989.

Peat. Manwick. Mitchell \& Co. Research Opportunities in Auditing. 1976.

Schilder, A., et al., Risico's en oordeelsvorming in de accountantspraktiik. (with English Summary, titled: 'Risk assessment and judgment in the Audit Profession), Limperg Institute, Amsterdam, 1991

Willingham, J. J. and T. J. Mock. 'An Improved Method of Docümenting and Evaluating a System of Internal Accounting Control:, Auditina: A Journal of Practice and Theory. Spring, 1983. 


\section{Acknowledgements \\ (Verantwoording)}

This lecture has benefitted from feedback gathered during a number of presentations including several universities in the Netherlands (Tilburg, Groningen, and Limburg), the United States, Canada, Australia and New Zealand. This particular version has profited from suggestions of Steven Maijoor, Arnold Schilder, Ganesh Krishnamoorthy and Susan Scholz.

I am particularly indebted to Professors Jan van de Poel and Arnold Schilder who have continued to make my visits to the Rijksuniversiteit Limburg both academically stimulating and enjoyable. My general interest in audit research, which was almost nil until the mid 1970's, has been stimulated and supported the University of Southern California, the Arthur Andersen Alumni Professorship at USC, by the Peat, Marwick, Main "Research Opportunities in Auditing" Program, by the US Fulbright Foundation and by the many doctoral students at USC and elsewhere I have had the pleasure of working with. To each of you a hearty dank u zeer! 